\title{
Speleological Geophysics - Methodology for the Application of Geophysics in Iron Cave Studies
}

Marcelo Roberto Barbosa*1, Marco Antonio Braga², Maria Filipa Perez da Gama², Rafael Guimarães de Paula1 and luri Viana Brandi ${ }^{1},{ }^{1}$ Vale S.A., ${ }^{2}$ UFRJ

Copyright 2019, SBGf - Sociedade Brasileira de Geofísica

This paper was prepared for presentation during the $16^{\text {th }}$ International Congress of the Brazilian Geophysical Society held in Rio de Janeiro, Brazil, 19-22 August 2019.

Contents of this paper were reviewed by the Technical Committee of the $16^{\text {th }}$ International Congress of the Brazilian Geophysical Society and do not necessarily represent any position of the SBGf, its officers or members. Electronic reproduction or represent any position of the SBGf, its officers or members. Electronic reproduction or
storage of any part of this paper for commercial purposes without the written consent of storage of any part of this paper for commercia
the Brazilian Geophysical Society is prohibited.

\begin{abstract}
The brazilian speleological heritage is protected by federal environmental laws, and in the case of mining, the licensing procedures require scientific studies that demonstrate that caves will not have impacts on their ecosystems. Blasting near mining caves is the activity that offers the greatest risk of damage to their physical structures. To mitigate the problem, geotechnical and geostructural studies are performed through conventional surveys and mapping, but in an invasive and not always possible way. In this context, the application of geophysical methods has been proving to have a great potential, much more extensive and complementary to the direct methods, allowing to know the interior of the massif and its structural framework, better subsidizing, therefore, stability studies of the caves. In order to organize and sequence the flow of the involved processes, this work proposes a methodology for the systematic use of near surface geophysics in speleological studies, in this case, the electrical resistivity, and presents an example of its application in a cave near the N4EN iron mine in Carajás, Brazil.
\end{abstract}

\section{Introduction}

The Brazilian federal laws, from 1988, include natural underground caves as Union assets. Since 2008, with the high demand for mineral commodities, this legislation has become more restrictive, requiring for the licensing of any enterprise a series of long and complex scientific studies that ensure the integrity of the cave ecosystem during operations (MMA, 2004 e Brasil, 2008).

The mineral industry was one of the most impaired when in cave regions, since blasting explosives is undoubtedly the greatest risk to their physical integrity. Therefore, to know the geostructural conditions and the geomechanical quality of the massif, as well as the degree of structural stability of the caves, are actions pursued by companies today, in order to comply with the legislation, trying to accelerate the licensing of areas.

In general, studies of the physical environment of natural caves, combining the different disciplines such as, structural geology, geophysics, geotechnics and rock mechanics, are well developed in the literature for carbonate caves, but very scarce for caves in ferriferous terrains (iron caves), whose peculiarity are the low depths (up to $30 \mathrm{~m}$ ) where they occur, usually at the edge of plateaus. However, there has been a substantial increase in these studies for iron caves in recent years, mainly in Brazil, due to the legislation.

In the geophysical literature there are important researches and projects with electrical, radar and seismic geophysical methods, practically all carried out in carbonate caves, even though they provide precious foundations for studies of iron caves. Some researches deserve attention, such as Pellerin (2002), that applied electrical and electromagnetic methods for geotechnical investigation of caves, and Manney et al. (2005), who explored the response of electroresistivity in a cave under different layered structural directions.

More recent geophysical projects for iron caves are described in Barbosa et al. (2016a, b), Barbosa et al. (2017), Prosdocimi et al. (2018) and Gama et al. (2018), and show that near surface geophysics can detail relevant underground geostructural aspects, imperceptible to conventional mapping methods, especially in the portions between the caves ceilings and the surface of the terrain, identifying more precisely their real zones of fragility.

In order to organize and sequence the flow of the processes involved in geophysical surveys of caves, the present work draws a methodology, called Speleological Geophysics, that was applied to an iron cave near the N4EN iron mine in the region of Carajás, southeast of the state of Pará, northern Brazil (Figure 1).

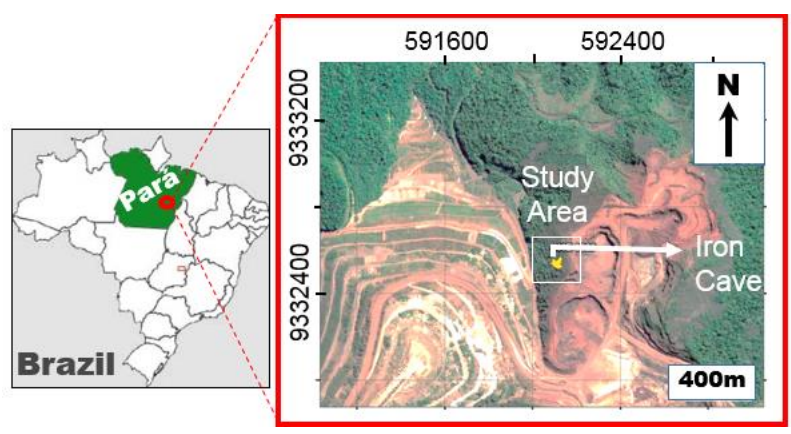

Figure 1 - Study area location map.

\section{Method \\ Speleological Geophysics Method}

This methodology was developed to facilitate the application of near surface geophysics in the investigation of iron cave ceiling litho-structural instability indicatives, 
through electrical contrast patterns. It should be used along with specific physical speleological studies, which deal with geological and geostructural issues (mapping and monitoring).

The methodology is presented in the form of a workflow, which identifies the main activities/steps and their sequencing. The workflow is greatly simplified, and it brings a series of numbered check items, which represent essential inputs or guidelines that cannot be forgotten, to better qualify the technical data base.

The methodology was divided into an initial stage, with three Technical Premises (for the technical database construction), followed by four Analytical Steps (which should always be applied to each geophysical section, be it control lines on cave surroundings or lines just over the cave), as displayed in Figure 2.

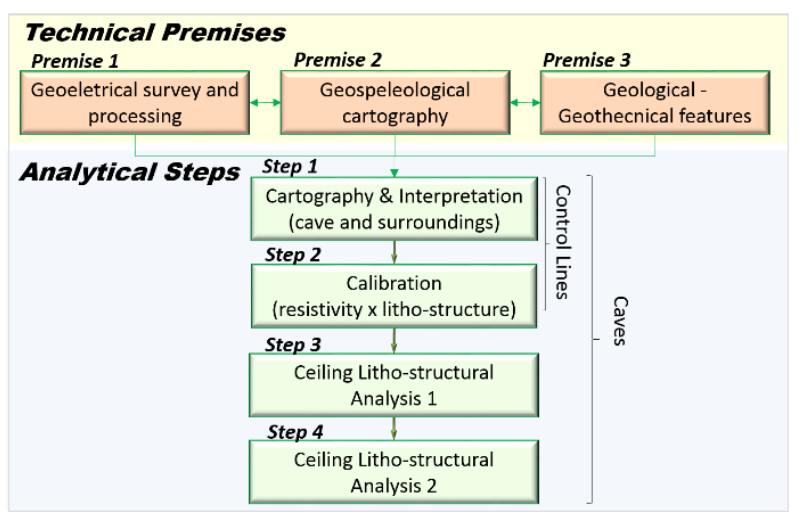

Figure 2 - Speleological Geophysics method

\section{Technical Premises}

This initial stage is considered the most important of the methodology, aimed at the collection of a database and consistent and complementary information. The quality of this database will reflect on the quality of the interpretation of the geophysical sections during the later analytical stage.

Three premises are sufficient for the construction of a consistent database and for each one, a set of selfexplanatory questions were thought to assist in this assembly:

\section{Premise 1 - Geoelectrical survey and processing}

Check 1 - Has the electrode array been tested? Is the data resolution acceptable?

Check 2 - Is the section long enough to reach the cave (floor/ceiling) and surroundings (calibration)?

Check 3 - Are the inversion parameters suitable? Are the ohm.m intervals fit?

Premise 2 - Geospeleological cartography
Check $1-$ Are there $5 \mathrm{~d}$ speleometry and 3D topography of the cavity?

Check 2 - Are there satellite images and panoramic photos (aerial and local)?

\section{Premise 3 - Geological-geotechnical features}

Check 1 - Are there geostructural and geomechanical maps?

Check 2 - Are there petrographic, mineralogical and geotechnical data?

\section{Analytical steps}

The interpretation stage must be performed by a geophysicist, along with a multidisciplinary team with experience in the geology and geotechnics of the cave and surroundings.

Step 1 - Cartography \& Interpretation (cave and surroundings) - Cartographic arrangement for positioning of the geophysical section in the context of the cave and surroundings, to better represent the correlations, analysis and interpretations.

\section{Step 2 - Calibration (resistivity $x$ litho-structure)}

Check 1 - Can it identify laterite/weathering profiles?

Check 2 - Can it work to recognize rocks and structures?

Check 3 - Is it influenced by relative humidity?

\section{Step3 - Ceiling litho-structural analysis I}

Check 1 - How deep is the cave's ceiling from the ground surface?

Check 2 - What is the spatial relationship between the electrical section and the cave?

Check 3 - Represent in detail the electrical section and the cave ceiling

Step4 - Ceiling litho-structural analysis II

Check 1 - Does it present angular contrast?

Check 2 - Does it present low resistivity contrast?

Check 3 - Does it present high/intermediate resistivity contrast?

\section{Results}

Speleological geophysics method applied in an iron cave

The proposed methodology was tested using the electro resistivity method in a 5-line array (1 Control Line outside the cave area, and 4 Lines exactly overlaying the area of the cave). 
This work will exemplify the application of the methodology for a geophysical line $L 1$, one of the lines that overlaid the cave.

\section{Line L1 - Technical Premises}

\section{Premise 1 - Geoelectrical survey and processing}

Check 1- Has the electrode array been tested? Is the data resolution acceptable?

It is fundamental to test several electrical configurations, and to select the one that offers the best performance. The most appropriate to the ferriferous terrain was the DipoleDipole array. This configuration showed a considerable signal-to-noise ratio as well as a satisfactory penetration depth versus lateral resolution. Electrode spacing of $1.40 \mathrm{~m}$ was maintained and delivered good resolution when the line was exactly overlaying the cave, and intervals of $2.80 \mathrm{~m}$ were used when beyond the cave.

Check 2 - Is the section long enough to reach the cave (floor/ceiling) and surroundings (calibration)?

The geophysical array for iron caves should take into consideration two main points: Lines perpendicular to the direction of the largest axis of development of the cave and/or positioned over specific locations of the cave (rooms with fragile ceilings for example). The transverse lines were extended to $170 \mathrm{~m}$ on average to reach the required $40 \mathrm{~m}$ depth, which is ideal for shallow subsurface caves in ferriferous terrains. In the case of the present test, the cave was $12 \mathrm{~m}$ deep approximately.

The control line must be acquired preferably at a place with exposed outcrops or with known lithology (e.g. over a mining bench), so that a calibration between the electrical signatures and the lithotypes and structures can be made. In this study, the control line was done on a mine bench in the surroundings of the cave, with $86 \mathrm{~m}$ in extension, reaching $20 \mathrm{~m}$ depth, attending to the needs of this investigation (the bench in the mine is $15 \mathrm{~m}$ high).

Figure 3 shows the study area with the cave floor plan projected on the surface, and the locations of the geophysical array overlaying it and the control line.

Figure 4 shows the 3D topographic map of the cave and the 4 electro resistivity lines sectioning the cave, proving its depth coverage, cutting the cave roof / floor.

Check 3 - Are the inversion parameters suitable? Are the ohm.m intervals fit?

For the treatment of the data in the iron environments, it is proposed the normalization of the sections, through a mean of the values of each resistivity range, considering, therefore, that the normalized values have the proper standard deviations to the real values. From these results, two important conclusions can be drawn. Firstly, the historical results analyzed show an excellent correlation of the geophysical data with the geological interpretations. Secondly, the results do not extrapolate the standard deviations of each resistivity zone. Therefore, the sections of the cave had the apparent resistivity values normalized, since the significant amount of data associated to it, allowed the extrapolation of the values to all sections, without loss of the reliability of the geophysical interpolation. Figure 5 shows the range and color scale adopted for the resistivity values. Note that there was a division for each zone, differentiating interval "+" "greater", and (-) "smaller", within the same zone. The objective was to give greater precision to the descriptions of correlations and interpretations between electric signatures and lithostructures.

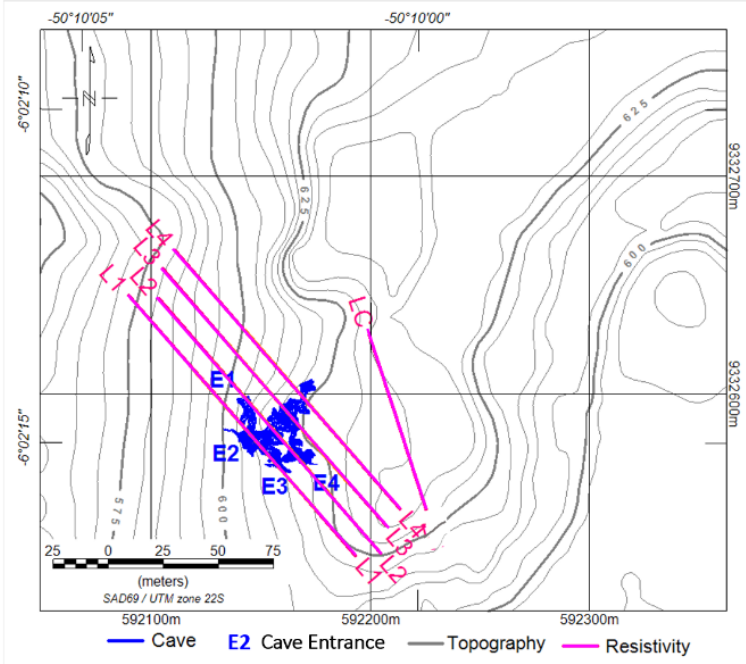

Figure 3 - Geophysical array overlaying the cave plan projected on the surface and the control line.

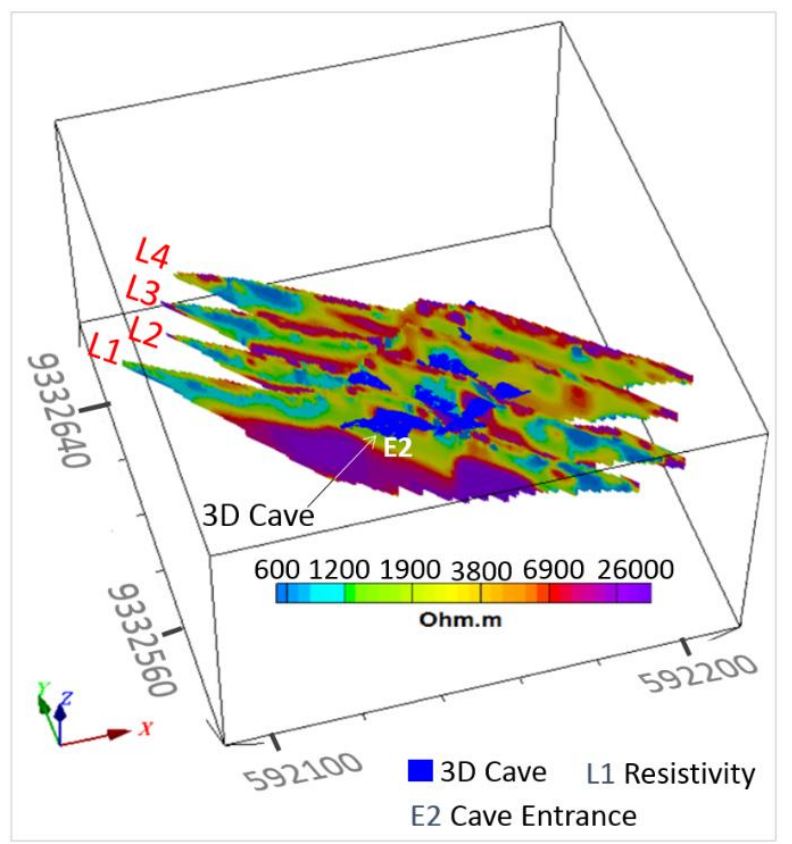

Figure 4 - Cave $3 D$ map with the 4 electroresistivity images sectioning the cave. 


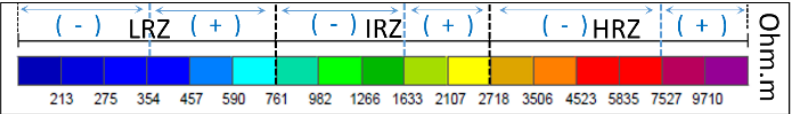

Figure 5 - Range and color scale adopted for resistivity values. Note that there was a division for each zone, in order to give greater precision in the correlations and interpretations $(L R Z=$ Low Resistivity Zone, $I R Z=$ Intermediate Resistivity Zone, HRZ = High Resistivity Zone).

The remaining two premises (Geospeleological Cartography and Geological-Geotechnical Features) will not be detailed in this work because they are very specific to speleological technical studies, out of the scope.

\section{Line L1 - Analytical Steps}

Step 1 - Cartography \& Interpretation (cave and surroundings)

The line L1 was planned overlaying specific locations of the cave that needed a more detailed investigation of the ceiling, indicated by the geostructural mapping. The line direction was oriented transversally to the main axis of development of the cave. Secondarily, its positioning focused to cross the main spans and conduits. Figure 6 shows the location of the line, and how it will be presented and interpreted. It is very important to precisely locate and identify the sectioned parts in the cave, since these are the ones that will have their ceilings investigated by geophysics. In the case of Line L1, three parts were crossed by the geophysical section and identified as: L1A $=$ Entrance $3 ; \mathrm{L} 1 \mathrm{~B}=$ Portion between a conduit and Entrance 2; and L1C = Entrance 2.

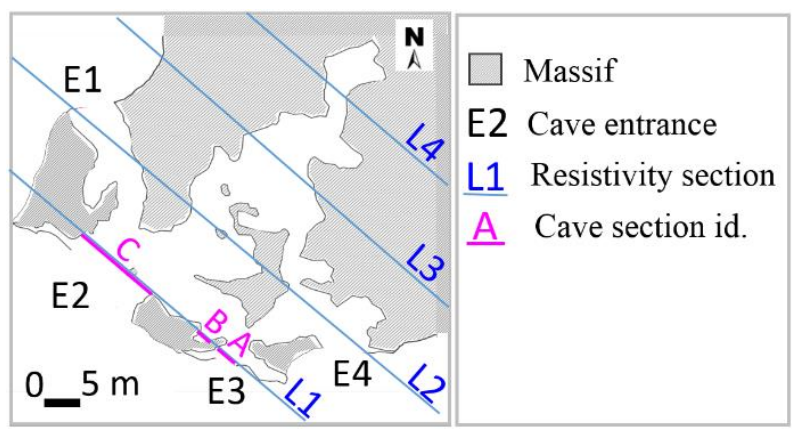

Figure 6 - Location of line L1 overlaying the cave floor plan. Note the three identified parts that were crossed by the geophysical section, and which will have their ceilings investigated.

Step 2 - Calibration (resistivity $x$ litho-structure)

\section{Check 1 - Can it identify laterite/weathering profiles?}

At this step it is important that the 3D cave section contour of the cave is represented graphically in the electrical section with topographic accuracy, so that the ceiling / floor portions are present and allow the delimitation of the area of detail that will be studied. The interpretation of the electrical section showed a good correlation between resistivity values and geology, marking the contact between the three typical weathering horizons of Carajás region: Lateritic Crust ( $\mathrm{HRZ}$ domain (> 2718 ohm.m)), Transition Horizon (IRZ domain (761 2718 ohm.m)) and Saprolite (HRZ domain (> 2718 ohm.m)), and their lithotypes (Figure 7).

\section{Check 2 - Can it work to recognize rocks and structures?}

The first weathering horizon, Lateritic Crust, was easily identified by its electrical signatures, with the lithotypes Detrital Lateritic Crust (DLC) occurring in low slope, and Ferruginous Lateritic Crust (FLC) at the top of the plateau and also on the surface of the terrain, over the cave. The Transition Horizon was dominated by the Aluminium Iron Laterite (AIL) lithotype, including cores of Lateritic Iron Formation (LIF), (Figure 7).

Structurally, two places present abrupt changes in electrical geometry, forming an angular truncation, which may be associated with planar discontinuities. This type of electrical contrast (Angular Contrast) is one of the anomalies that may be indicative of litho-structural instability (Figure 7).

Check 3 - Is it influenced by relative humidity?

The two places where the geophysical line cut the cave Entrances 2 (E2) and 3 (E3) were evaluated because of their high resistivity.

At Entrance 2, the geophysical line passes $5 \mathrm{~m}$ into the cave, and has high resistivity with (-) HRZ (2718-5835 ohm.m) and cores of (+) HRZ (> 7527 ohm.m). It is difficult to attest that this high resistivity refers only to the lithotype Lateritic Iron Formation (LIF), because of the relative humidity of $88 \%$ registered in Entrance 2 (average of 400 hourly measurements between November and December 2016), which would also make the resistivity high. This situation confirms Chalikakis et al. (2011) and Putiska et al. (2012) which clearly demonstrated the interference of relative humidity with the resistivity results and the difficulty of discovering a cave or its limits in subsurface. (Figure 7).

The geophysical line just cuts Entrance 3 . The high recorded resistivity of (-) IRZ (2718-7527 ohm.m) and cores of + HRZ (> 7527 ohm.m) refers to the Ferruginous Lateritic Crust (FLC) lithotype, but is probably subject to interference from the relative humidity of the air at Entrance 3 (no measurement), confirming the difficulty of delimiting the cave. (Figure 7).

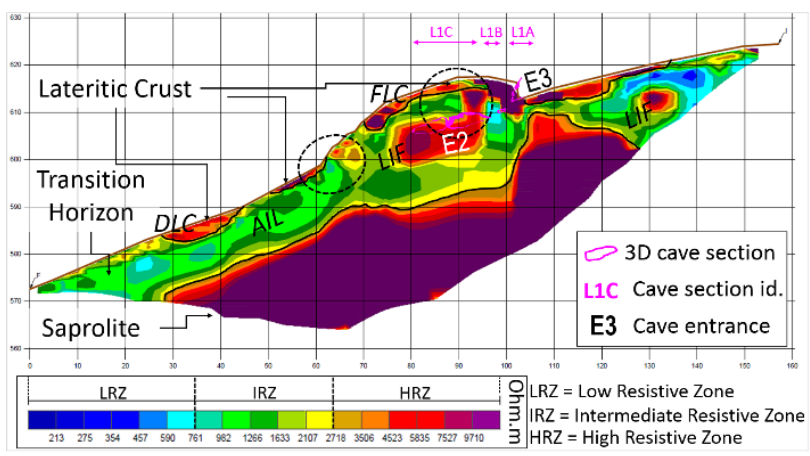

Figure 7-Electrical resistivity section of line L1. Note the weathering horizons and lithotypes, interpreted from their electrical signatures. The angular contrasts occur at the two places highlighted with a circle, referring to structural 
discontinuities. The two Entrances (E2 and E3) have high resistivity, which may be associated to both the lithotype and the relative humidity. (DLC $=$ Detrital Lateritic Crust, $F L C=$ Ferruginous Lateritic Crust, $A I L=$ Aluminium-Iron Laterite, LIF = Lateritic Iron Formation)

\section{Step3 - Ceiling litho-structural analysis I}

Check 1 - How deep is the cave's ceiling from the ground surface?

It is advisable to work in a 3D digital environment for a greater precision of these important measures of thickness between the ceiling and the surface of the terrain, in the parts where the resistivity line cuts the cave.

Check 2 - What is the spatial relationship between the electrical section and the cave?

It is necessary to perceive precisely how the cave is sectioned by the geophysical line, and to identify notable points as entrances, conduits and pillars, and to define the depths of the parts that will be investigated. (Figure 8)

Check 3-Represent in detail the electrical section and the cave ceiling

The detailed image (zoom) of the electrical section should be made representing the whole extension of ceiling to be interpreted. Figure 8 shows this zoomed image of line L1 sectioning the cave into three parts, identified as: $L 1 A=$ Entrance 3 ( $4 \mathrm{~m}$ thickness between surface and ceiling); $\mathrm{L} 1 \mathrm{~B}=$ Portion between a conduit and Entrance $2(7 \mathrm{~m}$ thickness between surface and ceiling); and L1C = Entrance 2 ( $8 \mathrm{~m}$ thickness between surface and ceiling).

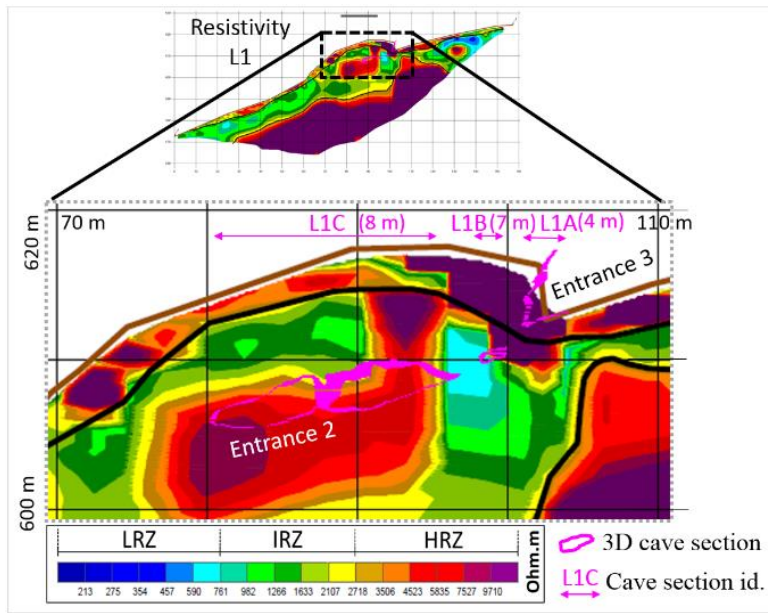

Figure 8-Detail (zoom) of the electrical resistivity section of line L1. Note the three parts that sectioned the cave, identified as: $L 1 A=$ Entrance $3(4 \mathrm{~m}$ thickness between surface and ceiling); $L 1 B=$ Portion between a conduit and Entrance 2 ( $7 \mathrm{~m}$ thickness between surface and ceiling); and $L 1 C=$ Entrance 2 ( $8 \mathrm{~m}$ thickness between surface and ceiling).

Step4 - Ceiling litho-structural analysis II

Check 1 - Does it present angular contrast?
The interpretation showed a sudden change of geometry of electrical signatures, passing from a sub horizontalized intermediate resistivity layers (761-2718 ohm.m) to a subvertical high resistivity (> $2718 \mathrm{ohm} . \mathrm{m})$, in the ceiling of Entrance 2, close to a pillar (Figure 9 - circle 1). Inside the cave, exactly in this place, a subvertical fracture was mapped. Also, a high resistivity core (+) HRZ (> 7527 ohm.m) identified in the ceiling seems to be related to a discrete block mapped between a subvertical fracture and a more angled fracture.

\section{Check 2 - Does it present low resistivity contrast?}

The low resistivity contrast (590-761 ohm.m) occurs in the middle of the ceiling/wall between Entrances 2 and 3, interlayered with high resistivity zones (> 2718 ohm.m). In this section, the lithotype Aluminium-Iron Laterite (AIL) with a clayey matrix was mapped. (Figure 9 - circle 2 ).

Check 3 - Does it present high / intermediate resistivity contrast?

It occurred in the ceiling of Entrance 2, close to the pillar, coincident with the span limit in the ceiling extension. It is at the interface between a High Resistivity Zone (75272718 ohm.m) and an Intermediate Resistivity Zone (2718761 ohm.m), (Figure 9 - circle 3).

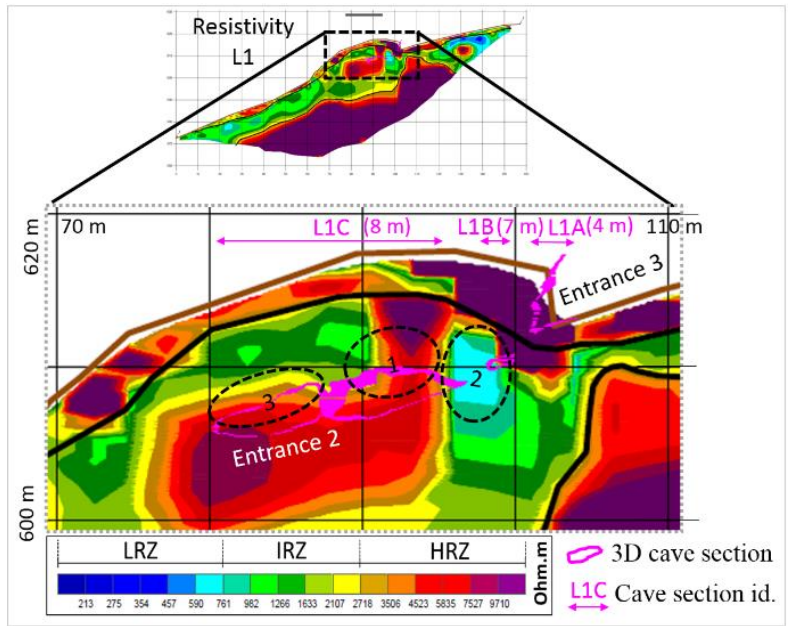

Figure 9 - Detail (zoom) of the electrical resistivity section of line L1. Circle 1 shows Angular Contrast in the ceiling of Entrance 2. Circle 2 shows the Low Resistivity Contrast (590-761 ohm.m). Circle 3 shows the High / Intermediate Resistivity Contrast coinciding with the ceiling extension at the opening of the Entrance 2.

\section{Conclusions}

The use of the proposed methodology (Speleological Geophysics) in a real case in an iron cave near a mine operation was demonstrated. The methodology was presented in a simplified workflow for easy implementation. It shows the application of near surface electrical resistivity, to assist speleological studies, in the investigation of lithostructural instability of cave ceilings. 


\section{Acknowledgments}

The authors would like to thank Vale S.A. for the data and permission to publish this work.

\section{References}

BARBOSA, M.R.; DE PAULA, R.G.; BRAGA, M.A.; BRANDI, I.V.; CLAUVER, C.; MATOS, J.; SEBASTIÃO, C. 2016a. Aplicação do Método Ground Penetrating Radar (GPR) no Mapeamento Geoestrutural de Cavidades Naturais Subterrâneas em Terrenos Ferríferos - Estudo de Caso da Mina N4E, Carajás. In: Simpósio Brasileiro de Mecânica das Rochas - SBMR, Belo Horizonte. [s.n.]

BARBOSA, M.R.; DE PAULA, R.G.; BRAGA, M.A.; BRANDI, I.V; CLAUVER, C.; MATOS, J.; DIAS, L.S.O. 2016b. Métodos Geofísicos Aplicados a Coberturas Lateríticas com Feições Pseudocársticas na Mina de Ferro N4E, Carajás. In: VII Simpósio Brasileiro de Geofísica SimBGf, Ouro Preto. MG. [s.n.]

BARBOSA, M.R.; BRAGA, M.A.S.; BRANDI, I.V.; DE PAULA, R.G.; ARAÚJO, R.N.; PROSDOCIMI, G.; DIAS, L.S.O. 2017. Geofísica Rasa na Investigação GeológicaGeotécnica de Cavidades Naturais Subterrâneas na Mina de Ferro N4E, Carajás. In:15th International Congress of the Brazilian Geophysical Society, Rio de Janeiro. [s.n.]

BRASIL. Instituto Brasileiro do Meio Ambiente e dos Recursos Naturais Renováveis, Resolução IBAMA no 887, 15 de junho de 1990. Delibera sobre o patrimônio espeleológico nacional e delimita a área de influência das cavernas naturais. Diário Oficial da União, № 117, Seção I, Pág. 11844. 20 de julho de 1990. Available at: www.ibama.gov.br/cecav/download.php?id_download=47 Accessed in February 26, 2018.

CHALIKAKIS, K.; PLAGNES, V., GUERIN, R.; VALOIS, R.; BOSCH, F. P. 2011.Contribution of geophysical methods to karst-system exploration: an overview. Hydrogeology Journal, 19, 1169-1180.

GAMA, M.F.P.; BARBOSA, M.R.; BRANDI, I.V.; BRAGA, M.A.S. 2018. Caminhamento elétrico aplicado ao mapeamento de cavernas naturais em minério de ferro, Carajás (PA). In: 49ํㅡㄹ Congresso Brasileiro de Geologia, Rio de Janeiro.

MANNEY, R.; ROTH, M.J.S.; NYQUIST, J.E. 2005. Exploring Directional Differences in Resistivity Results in Karst. In: Proceedings for SAGEEP, Oakland, California, 2005. p. 1117-1124.

MMA. Resolução CONAMA n ${ }^{\circ} 347$, de 10 de setembro 2004. Dispõe sobre a proteção do Patrimônio Espeleológico. Diário Oficial da União, 13 de setembro de 2004. Available at:

http://www.mma.gov.br/port/conama/legiabre.cfm?codlegi $=452$. Accessed in February 26, 2018.

PELLERIN, L. 2002. Applications of Electrical and Electromagnetic Methods for Environmental and Geotechnical Investigations. Surveys in Geophysics, 23, 101-132.

PROSDOCIMI, G.; BARBOSA, M.R.; BRANDI, I.V.; BRAGA, M.A.S. 2018. Estudo de caverna natural em formação ferrífera por meio da integração de métodos geofísicos rasos, Complexo Carajás, Brasil. In: 49ํㅡㄴ Congresso Brasileiro de Geologia, Rio de Janeiro.

PUTIŠKA, R., NIKOLAJ, M., DOSTÁL, I., \& KUŠNIRÁK, D. 2012. Determination of cavities using electrical resistivity tomography. Contributions to Geophysics and Geodesy, 42(2), 201-211. 